\title{
In the Context of Visual Pollution: Effects to Trabzon City Center Silhoutte
}

\author{
Demet Yilmaz \\ Department of Architecture, Karadeniz Technical University \\ PO box 61080, Trabzon, Turkey \\ Tel: 90-462-377-3542_E-mail: yilmazdemett@hotmail.com \\ Ayşe Sağsöz (Corresponding author) \\ Department of Architecture, Karadeniz Technical University \\ PO box 61080, Trabzon, Turkey \\ Tel: 90-462-377-7777 E-mail: sagsoz@ktu.edu.tr
}

Received: November 4, $2010 \quad$ Accepted: November 23, 2010 doi:10.5539/ass.v7n5p98

The research is financed by Asian Development Bank. No. 2006-A171 (Sponsoring information)

\begin{abstract}
One of the clearest indicators of visual pollution in the cities are their silhouettes. Silhouettes are the faces of physical structure and historical accumulation of cities. But today many cities are full of buildings that are incompatible with each other, that are disrespectful to the environment and that have no identity. Generally, city silhouettes consist of concrete façades, they have changed into common appearances that do not stamp themselves in people's minds, and the historical environments have disappeared in this chaos.

Trabzon is a coastal city where green and blue meets and which were famous for its orchards, tangerine gardens and terraces that reached the coast. But rapid and unplanned urbanization is changing the city. Moreover, with its history of thousands of years, it is not possible to see these riches effectively in the city which carries the traces of different civilisations.

This paper seeks to investigate the traces of change and transformation that the city has undergone in the silhouette of the city. Interventions in the city and visual pollutions in the city silhouette as a result of these interventions will be considered. In this context, by comparing the new photos of the city with the old ones, the aesthetic value and visual quality of the city will be evaluated.
\end{abstract}

Keywords: Trabzon, Silhouette, Visual pollution, Visual quality

\section{Introduction}

Throughout history, people have formed their environments and their environments have formed them. In this cycle, it is possible to see the traces of change in the lives of the societies within the spaces that are integrated with them. After the 1950's, especially after the industrial revolution, the rapid and unplanned urbanization in Turkey, rapid and unplanned rural-urban migration, and the resulting rapid population growth etc. caused many changes, and all these affected the environments in which people lived.

One of the clearest indicators of visual pollution in the cities are their silhouettes. Silhouettes are the visible faces of the physical structures and historical accumulation of the cities. But today many cities are full of buildings that are incompatible with each other, that are disrespectful to the environment, that have no identity. Generally, they have changed into common appearances of poor quality that do not stamp themselves in people's minds.

Throughout history, human beings have continuously been in attempts to change their environments according to their desires. The demands of the growing population and developments in the industry caused some changes in the environment, which brought about various environmental problems.

When we speak about environmental problems, the first things that come to mind are land, water, air and noise 
pollutions. However, a type of pollution which is becoming more and more important recently and which affect people psychologically and spiritually but which is not considered important among other types of pollution is visual pollution. Visual pollution is defined as making some negative changes in the natural environment and, in this way, turning the visual areas of healthy people into something that disturbs them (Bodur \& Kucur, 1994, p.56). Visual pollution can also be defined as the whole of the irregular formations which are generally found in natural and built environments, which is usually seen indirectly, and which leaves negative impressions in the minds of people (Öner \& Konakl1, 2009, p. 499).

Some of the reasons for visual pollution in the cities are as follows: wrong decisions, legal deficiencies, lack of control, uses that are not compatible with the functions, lack of education and culture, and insensitivity of local administrations, etc (Öner \& Konakl1, 2009, p. 500). The reflections of visual pollution can be seen in the whole of the city as well as in the details which are parts of the buildings or urban spaces.

Environments with monotonous and dense structuring and without green elements and an original character, and neglected buildings with disproportinate number of floors and badly planned transportation systems create visual pollution. In addition, the wheeled bins, signboards, and direction signs in the details of buildings and urban spaces; the large billboards in the entrances and exits of the city; the electric poles and wires, transformer buildings, telephone cables, air conditioners attached to the outer walls of the buildings, and satellite dishes also create visual pollution.

People are constantly interaction with their environments. There is a continuous balance between human beings and their environments. The deterioration of this balance has such negative effects on people as distraction, eye fatigue, reluctance, unproductivity, decrease in opinion diversity, decrease in stimulation, adaptation difficulties, nervousness, behavioral disorder, pessimism, nausea, psychic trauma, decrease in joy of living, increase in psychosomatic illnesses, and vertigo (Bodur \& Kucur, 1994, p. 51).

All people have the right of quality living. The Article 56 of the constitution of the Republic of Turkey reads, 'Everyone has the right to live in a healthy and balanced environment. It is the duty of the state and citizens to improve the natural environment, and to prevent environmental pollution' (Türk Çevre Mevzuat1, 1999, p. 132).

The famous Spanish philosopher, Ordegay Gasset (1883-1955), said, "the good part of my soul is the gift of sights, if I had spent my lifetime in savagery of cities, now I would be more mild-mannered and deeply thoughtful person. Tell me which sight/environment you want to live, I say who you are /what your character is", which, emphasizes the effects of the visual qualities of cities and the development and changes in these cities on the people (url 1).

The silhouette of a city can be defined as the concrete appearance of the character of a city, and the material appearance of its history, culture, power of survival, the philosophy of its dead and living people (Oktay, 2002, p.235). Moreover, city silhouettes are the basic references points to understand the city form, and they present references about the whole city in the aesthetic evaluation of the city. Around the monument or many monuments which dominant to the general appearance, silhouette, which have identification feature for the city, is composed combination of repeated elements as local forms of roof, dooms, towers, minarets A silhouette which has a defining characteristics is created by the collection of such repeating elements as local roof types, domes, towers and minarets around one or more monuments that dominate the general view (Demirkesen, Özlüdemir \& Demir, 2005, p. 133).

Krampen (1979) states that the coastal silhouette of a city is diversified with historical additions. This diversity is created by a combination of buildings and urban textures of different times. In case of little diversity in the urban silhouette, a monotonous appearance is created by similar structures which are built side by side. At the same time, a combination of structures and textures which are not in harmony with each other also cause a disturbing chaos for the observers ( Bostanc1, Ocakçı \& Şeker, 2006, p. 83). Diversity in the city silhouette expresses the originality among the parts of the environment that complement each other and the harmonious differences that create visual richness. It also increases the attractiveness and remembrance of the city and provides slection possibilities (Jacobs 1980, Berlyne 1960; Bostanc1, Ocakçı \& Şeker, 2006, p. 85).

Massey (1994) states that the identity of a space cannot be separated from its spatial features, and that it is the expression of a specific situation which results from the communication between the user and space. On the other hand, Abel (1997) indicates the necessity for the emphasis on the quality of impressiveness in the creation of the identity of space, and claims that this can only be achieved by being based on formal expression that may present an unlimited number of ideas. And Correa (1983) says that identity is a process, that it can't be produced and that it can't be something that is made intentionally. According to Gürsel (1993), identity is the product of a style of existence. The creation of an identity is the result of the continuity of specific conditions (Kancioğlu, 
2005, p. 51).

Theorists of modern psychology state that identity is a very special case that is peculiar to the individuals or society, that it is evolved not from the being itself but from its interaction with others, and that it is something that can be described by comparing it with others. Furthermore, it is also stated that the characteristics which form the identity necessarily correspond to the perceptible formal characteristics, even if they are abstract or belong to the self (Balamir 1993, p. 29). In the cities, one of the basic elements that makes up the urban texture and that is considered as the reflection of the culture of the society is architectural structures. Buildings in different cities reflect the different ways of living and cultures of different societies, and at the same time they form the visual identity of the cities. Silhouettes which are the visible faces of cities are also important as the indicators of urban identity.

According to Lynch (1960), the readability of urban space is the easy perception of the urban space and the facility of organization of it as a certain texture An orderly and readable urban space can be a concrete reference system, or activity and information regulator. He lists the paths, edges, districts, nodes and landmarks as the readability elements of the urban space. He states that harmony, arrangement, and simplicity are the necessary features for readability of an environment (Lynch, 1960, p. 3). According to Kaplan (1982), readability is an environmental feature which enables people to explore their environment comprehensively without getting lost (Nasar, 1988, p. 300-320). On the other hand, Aydınlı (1999) claims that the readability of an environment is the regeneration of the visual images and codes of the urban space with interconverting concepts (Erem \& Erkman, 2003, p. 52).

Historical-cultural heritage is a limited and nonrenewable resource which links the past and future, which can establish the communication between generations, which can solve the identity problem by developing a sense of belonging to somewhere, to a nation, or to a culture (Kipper, 2004, p.14). With the reflection of these values in the space, the readability and perceptibility of a city increase.

Lynch (1960) concludes that the perception of the urban texture is formed by the images which are created in one's memory. Lynch (1960) concludes that the perception of the urban texture is formed by the images which are created in one's memory. According to Lynch (1960), cognitive mapping is made up of a series of psychological transformations by which an individual can acquire, code, store, recall, and decode information about the relative locations and attributes of phenomena in their everyday spatial environment (p.9).

Cities reveal their differences in both their social and cultural structure; the observers selects, orders them, and associates them with what they see according to their meaning. At this point, silhouette is one of the guides for observers. In this sense, silhouettes have an important role in the creation of an urban identity, in the readability of the city and in the creation of an image in human mind.

\section{The Area of Work: The City of Trabzon}

\subsection{Historical Development of The City of Trabzon}

Trabzon is in the Eastern Black Sea region and has an important geographical and strategic position. For centuries, it has been an important port, commercial and cultural center and assumed a complete control in the trade with the east.

Although the founders and foundation date of the city are not known, it is believed that it was founded in the 2000s B.C. Some sources claim that the city was founded 756 B.C (Anonymous, 1968, Bijışkyan ,1969, Aysu, 1982, p. 182; Özbilen, 1996, p. 101). For some time, Trabzon fell under Persian domination. In the first century B.C., the city was annexed to Roman Empire. In the end of the fourth century A.D., the Roman Empire was divided into two and Trabzon became part of the Eastern Roman Empire, which was also known as the Byzantine Empire. Although the city of Trabzon was formerly besieged by Anatolian Seljuks and Mongolians, it was annexed to the Ottoman Empire in 1461 during the reign of Sultan Mehmet II (the Conqueror). The city was captured by the Russians during the First World War. However, Trabzon again became a part of the Republic of Turkey in 1923 (Dilâver,1987, p. 12). The traces of all these civilizations, monasteries, churches, badastans (covered bazaars), inns and examples of civil architecture, create a rich mosaic.

The first core of the city is the castle. It is a settlement on top of a hill protected with walls. The area is surrounded on two sides by Tabakhane and Zaganos creeks, and the other sides are protected with walls. However, the castle lost its shape in time, and another castle that surrounds the first was created. The outer castle, on the other hand, starts from the Zaganos Creek, extends to the west, and turns north at Zaganos tower. The north and west sides of the area are on the coast. This part is called Aşağı Hisar (literally Lower Castle). At the end of Aşağı Hisar, an antique port was found, but it was destroyed in 1965 during the construction of the coastal 
road. The city which completed its development inside the castle extended as far as Çarşı, Pazarkapı, Kemerkaya, İskenderpaşa and Kalepark, the north of Cumhuriyet Mahallesi. In time, the city expanded to all areas that were suitable for settlement (Table 1).

\subsection{The Historical Process of the Development Plan for the City of Trabzon, and Its Negative Effects on the Important Quarters of the City}

The planned development of Trabzon started with the report prepared by J.H.Lambert in 1937. This report covers the following items: collecting activities at a certain point; constructing horizontal roads parallel to the sea on the east-west direction; constructing roads towards the hinterland on the north-south direction and connections for these that will provide ventilation; developing a land for settlement on the west of Imaret neighborhood and constructing parks, view points, cultural centers; and preserving the archaeological areas. This report was followed by the 3rd General Inspector Tahsin's report in 1939, the Analytical Surveys of Trabzon in 1967, the contest organized by the Provincial Bank of Turkey, and the revised development plans (Özbilen, 1996, pp. 101-114).

In order to meet the transportation needs of the city, the first coastal road was constructed in 1964 (Zorlu, Aydintan \& Engin, 2010, p. 58). This road completely destroyed the coastal character of the city. In time, the road fell short of meeting the traffic needs of the city, and recently the road was widened on the lands that were reclaimed from the sea. This destroyed the Ganita, Kemerkaya, Moloz and çömlekçi ports, the coastal settlements, and the culture of living blended with the sea. Another road that created a dramatic change in the city is the Tanjant Road. Although it was debated especially by the non-governmental organizationd for fear that it would interfere with the historical texture of the city, it was approved in 2002 and was constructed. The road traverses the city center, and because it is in the areas where the historical texture of the city is, it has had a negative impact on the historical texture. The most prominent example to be given here is the historical city walls. At the point where Tanjant Road meets the valley, the road was connected to the other side of the valley through a viaduct. The walls remained under the concrete viaduct, and consequently, their perceptibility decreased and a visual chaos was created. All interventions in the city harmed primarily the historical texture of the city, and these interventions either completely destroyed the riches that give an identity to the city or they crushed the historical texture under the new structuring. The traces of these destructions are more visible in the history of the city and therefore in Çömlekçi, Moloz, Kemerkaya, Ganita, and Faroz which contribute much to the silhouette of the city. In the study, by comparing the old and new photos of these quarters of the city, the silhouettes that emerged after the above mentioned applications were evaluated in terms of aesthetic value, visual quality and visual pollution (Figure 1,2).

\section{Method}

The study aimed to identify the negative consequences in terms of visual quality and pollution caused by the planning works in the whole of the city of Trabzon. To this end, the study employed the folowing method:

- Collecting theoretical information on the establishment and historical process of the city,

- Starting from the first development plan, identifying all development plans that have been made up to the present day,

- Identifying the quarters that have become the symbol of the city and that enriched the city in its historical development, and collecting information and documents about these quarters (by making use of archives). The study investigated such quarters of the city as Çömlekçi, Moloz, Kemerkaya, Ganita and Faroz.

- Documenting these quarters by photographing them from the sea and coast for the purpose of identifying their present conditions,

- Unveiling the changes in these areas by comparing the old and new documents,

- Evaluations and conclusions.

\section{- Çömlekçi and Güzelhisar Areas}

Çömlekçi is the biggest natural port of Trabzon and Güzelhisar the longest point projecting into the sea. In 1910, Güzelhisar's texture was clearly readable, and its examples of civil architecture were creating a strong texture with their recurrent façade characteristics. Green, sea and structuring were in an authentic complementarity. However, it has been observed that this authentic and characteristic texture has been replaced by chaos. It was found that the reference points that can be taken in the silhouette are not authentic architectural buildings but they have become prominent with their ovewhelming masses (Figure 3).

\section{- Ganita Area}


Ganita was the place where the people of Trabzon learned how to swim on its rocky shores, where they swam, where they watched the sunset, and where they had breakfast. However, the widened coastal road, the high buildings that are parallel to the road and the interventions in its natural structure with terraces decreased the number of its characteristics.

Although Trabzon is well known with its streets that are parallel to the sea and with its buildings that are compatible with its sloping ground, the multi-storey buildings suddenly rose against the topography with the process in which intense and tall construction reached its peak. High buildings not only harm the historical texture but also negatively affect the historically symbolic buildings that help the readability of the city and that have a landmark characteristic. For example, the St. George church was once an important reference point in the silhouette, but today it is not extant (Figure 4).

\section{- Kemerkaya Area}

The tunnel that passes by the Ganita Cafeteria connects the coastal road to the port. The Genoese and Venetians built a castle on a position which is above the tunnel and which overlooks the port, known today as Kalepark. Then, in the 18th century, the governor of Trabzon, Ahmet Pasha III, built a magnificant three-storey palace in the area, but it was demolished after his death (Akın, 2003). While in 1890 Güzelhisar had an overlooking position, today the new buildings suppress the castle both with their masses and forms (Figure 5).

The Teacher Training School in Kemerkaya neighborhood was built by Kakudilis, an engineer, in 1889. The building has served for various purposes and today it is used as a high school. This building has a high historical value but today it is lost among the new buildings. The waves were once beating the front of the building, but today there is a coastal road between the building and the sea, and its perceptual prominence decreased because of the high buildings around it (Figure 6).

\section{- Moloz Area}

Moloz is an area with an intense commercial activity. In the past, this area of the city was a coastal area, but today Moloz and the sea have become distant due to the coastal road that was built between Moloz and the sea. The peak that the structuring reached is remarkable (Figure 7).

\section{- Faroz Area (Numune Hospital Area)}

Numune Hospital is one of the reference points that is distinguished as a whole. However, high buildings around it have decreased its perceptibility (Figure 8).

\section{Evaluations and results}

Trabzon is an important and historical city in the Eastern Black Sea Region. Clavijo defines Trabzon as a city overlooking the sea. Aşı Mehmet reports that it is a city that has two walls and two castles, that the north of the walls is sea while the East, West and South of the walls are populated by three large settlements and by vineyards and orchards. On the other hand, Katip Çelebi, the great traveler, defines Trabzon as a green provincial center with many natural beauties while Deyrolle compares it with an amphitheater founded on the coast (Beyazl, 2005). All these travel books emphasize the relationship of the city with the green and sea, the power of environment-human interaction, and the place/importance of such spaces in the lives of people. However, in the modern day, the cities have started to lose their characteristic features as a result of fast urbanization and to transform into poor quality environments.

In this context, the study found the following:

*Based on the historical development of the city, when the physical structure of the city is examined through its silhouette, it becomes clear that such effective areas of the city as Çömlekçi, Moloz, Kemerkaya, Ganita and Faroz are self-perceived. Trabzon is known as a historical city due especially to its being a coastal city and due to its location on the hisorical silk road. However, it was found that the coastal road which was constructed in recent years has put an end to the human-sea relationship, which has reduced the visual and functional uses of the sea by the people.

*Another road that created a dramatic change in the city is the Tanjant Road. It passes through the center of the city. Although the construction of the road sparked much debate on its possible intervention in the areas which house an intense historical texture, the road crossed over the historical city walls of the city and therefore had a negative effect on the historical texture.

* The disconnection between the natural and artificial environments results in low quality and unreadable environments. In this regard, it was found that especially the new coastal road has affected the city negatively. 
*Because of the increase in the number of highrise buildings as a result of the negative interventions in the physical and visual qualities of the city, the reference points that can be taken in the silhouette of the city are in a process of change. This reduces the readability of the city.

*The dense and high buildings have an adverse effect on the topographic structure of the city. In addition, the perceptibility of the important buildings that enrich the city and that ensures the historical sustainability is diminishing. For example, the St. George church which was once very effective on the city silhouette has not been perceptible today.

*When we have a close examination, we see that the electric posts, signboards and billboards that are not designed properly and the mass-production urban furniture increase the visual pollution. Yet, urban furniture are the complementary elements in an urban area, and they are very effective in providing the radability and visual sustainability.

The identity of an individual is shaped in the environment in which he lives. His identity is shaped by his perceptions of his past, knowledge, experiences, thoughts, behaviors, expectations from or predictions for the future, needs, and the customs, beliefs and expectations of his society. The social structure is shaped under the influence of the culture of the society.

Individual identity is the sub-component of the group and social identity. Therefore, individuals affect the society, and the society affects the physical structure, and the created structure affects the society and therefore the individuals. In this way, the effects of the urban areas, which are the built-up areas, on the individuals and societies become self-evident.

If a city is unable to integrate its past characteristics with its modern needs, then the historical and cultural continuity is damaged, and this is the situation in which loss of identity appears. A process is necessary for the creation of an urban identity. Just like the city itself, the identity of the cityalso has time dimension.

As a result of the changing conditions, the development and change of cities are inevitable. However, when trying to solve such problems, all planning activities must be human oriented, and the aim must be to create cities which do not alienate the users from the city, whose historical continuity has been maintained, and which are high quality with a character. When the environment is being formed, it is necessary that the existing natural and socio-cultural riches be preserved, used, and maintained for the identity and social memory.

\section{References}

Abel, C. (1997). Architecture and identity-towards a grobal eco-culture. Oxford: Architectural Press.

Akın, S. (2003). Karadenizin kıyısındaki tavuzkuşu. Trabzon Dergisi, 9, 9-19.

Aydınlı, S. (1999). Kentsel mekanı okumak, görüngübilim bakış açısıyla kentsel mekan, Türkiyede Kentsel Tasarım ve Uygulamalar Sempozyumu 10 (pp.155-165). Istanbul: Yem.

Aysu, E. (1982). Trabzon Kenti Planlama Çalışmaları, Türkiye Birinci Şehircilik Kongresi: Vol.II (pp.182). Ankara: Orta Doğu Teknik Üniversitesi Yayını.

Balamir, A. K. (1993). Mimarın kimlik, meşrutiyet, etik sorunları ve mimarlığın disipliner buhranı, Türkiye Mimarllğı Sempozyumu II.Kimlik- Meşrutiyet-Etik. (pp. 24-30) Ankara: Mimarlar Odası Yayınları.

Berlyne, D.E. (1960). Conflict, Arousal and Curiosity. New York: Mcgraw-Hill.

Bıjışkyan, P. M. (1969). Karadeniz Klyıları Tarih ve Coğrafyası, (H.D. Andreasyan Çev.).İstanbul: İstanbul Üniversitesi Edebiyat Fakültesi Basımevi. (Original work published 1817-1819).

Bodur, S. \& Kucur R. (1994). Görüntü kirliliği üzerine. Ekoloji Dergisi, 12, 50-51.

Bostancı, S. H., Ocakçı M., \& Şeker S. (2006). Kentsel silüetinin çeşitlilik açısından değerlendirilmesinde antropi yaklaşımı. Journal of İstanbul Kültür University, 2, 83-95.

Correa, C. (1983). Quest for identity, architecture and identity, exploring architecture in islamic culture, I. Seminar, Universiti Tegnologi Malaysiz And Ministry Of Culture Malaysia 25-27 July pp.10-13.

Demirkesen, A.C., Özlüdemir, M.T. \& Demir H.M. (2005). Kapadokya örneğinde tarihi ve kültürel mirasın korunması ve bu işlemlerde harita mühendislerinin yetki ve sorumlulukları, 10. Türkiye Harita Bilimsel ve Teknik Kurultayl Ankara: TMMOB Harita Ve Kadastro Mühendisleri Odası, 129-139.

Dilâver, S. (1987). Tarihçesi ve tarihi yapılarıyla Trabzon. Trabzon Dergisi, 1, 12-20.

Erem, Ö. \& Erkman, U. (2003). Tatil köylerinin okunabilirliğinde çevre işaretlerinin rolü. Itüdergisi/a, 2, 51-59. 
Gürsel, Y. (1993). Değişme koşulları kimlik-meşrutiyet-etik, Türkiye Mimarlı̆̆ Sempozyumu II. Kimlik-Meşrutiyet-Etik (pp. 38-42), Ankara: Mimarlar Odası Yayınları.

Jacobs, A. B. (1980). Making city planning work. USA: American Planning Association.

Kancıoğlu, M. (2005). Çevresel imaj, kimlik, ve anlam kapsamında turizm binalarına ilişkin kullanıcı değerlendirmeleri. Uludağ Üniversitesi Mühendislik Mimarlık Fakültesi Dergisi, 2, 49-62

Kaplan, S. \& Kaplan, R. (1982). Cognition and environment; functioning in an uncertain world. Ann Harbor, MI: Ulrich.

Kipper, P. (2004). Küreselleşme sürecinde kentlerimize giren yeni tüketim mekanları ve yitirilen kent kimlikleri. Şehir Plancıları Odası, Planlama Dergisi, 4, 14-18.

Krampen, M. (1979). Meaning in the urban environment. New York: Pion Limited.

Kumbaracıbaşı, C. (1991). Çevre Kirlenmesinin Üçüncü Boyutu: Görsel Kirlenme, Ankara.

Lynch, K. (1960). The image of the city. London: The Mit Pres.

Massey, D. (1994). Space and gender. Minneapolis: University of Minnesota Press.

Nasar, J. L. Ed. (1988). The effect of sign complexity and coherence on the perceived quality of retail scenes, environmental aesthetics. Cambridge: Cambridge University Press. pp. 300-330.

Oktay, O. (2002). Bir başka Istanbul. İstanbul: Kubbealtı Neşriyatı Yayıncılık.

Öner, S. \& Konaklı, N. (2009). Konya Kentinde Görsel Kirliliğe Neden Olan Uygulamalar ve Çözüm Önerileri, V. Uluslararası Çevre Kongresi, pp. 498-506. Ankara: TMMOD Çevre Mühendisleri Odası.

Özbilen, A. (1996). Havada Suda ve Görüntüde Kirlenme Trabzon İli Kıyı Yönetimi. Ankara: Trabzon Vakfı, pp. 101-114.

Trabzon Kanuni Anatolian High school. [Online] Available: http://www.kanunianadolu.k12.tr/tarihce.asp (April 7, 2010).

Trabzon Kentinin Tarihsel Yapısı ve Gelişimi Trabzon Analitik Etüdler 1967-68. (1968). Ankara: İller Bankası Yayınları.

Türk Çevre Mevzuatı. (1999). (No. 134, 132-133). Ankara: Türkiye Çevre Vakfı Yayını, Önder Matbaa.

Zorlu, T, Aydıntan, E. \& Engine E. (2010). Kent kimliği: Tanjant ve Karadeniz Sahil Yollarının Trabzon kent kimliğine etkileri. Mimarlık Dergisi, 352, 54-59. 
Table 1. The Historical Development of the City of Trabzon, and City Planning Works

\begin{tabular}{|c|c|}
\hline \multicolumn{2}{|c|}{ Historical Development of the City of Trabzon } \\
\hline $\begin{array}{l}\text { Between } 2000 \text { B.C and } \\
50 \text { A.D. }\end{array}$ & $\begin{array}{l}\text { Settlement in the period of Liberation and Free City: The whole of } \\
\text { Ortahisar neighborhood, parts of Pazarkapı and Çarş1 neighborhoods }\end{array}$ \\
\hline $\begin{array}{l}\text { Between } 50 \text { A.D. and } \\
395 \text { A.D. }\end{array}$ & $\begin{array}{l}\text { Settlement in Roman period: Çarşı, Kemerkaya, İskenderpaşa } \\
\text { neighborhoods }\end{array}$ \\
\hline $\begin{array}{l}\text { Between } 395 \text { A.D. and } \\
1204 \text { A.D. }\end{array}$ & $\begin{array}{l}\text { Settlement in Byzantine period: Hizırbey and part of Gülbaharhatun } \\
\text { neighborhoods }\end{array}$ \\
\hline $\begin{array}{l}\text { Between } 1204 \text { A.D. } \\
\text { and } 1461 \text { A.D. }\end{array}$ & $\begin{array}{l}\text { Settlement in Comnenos period: Parts of Yenicuma and Cumhuriyet } \\
\text { neighborhoods }\end{array}$ \\
\hline After 1461 A.D. & $\begin{array}{l}\text { Settlements in the Ottoman period: Parts of Gülbaharhatun and Erdoğdu } \\
\text { neighborhoods }\end{array}$ \\
\hline $\begin{array}{l}\text { Between } 1530 \text { and } \\
1800\end{array}$ & $\begin{array}{l}\text { Settlements in the Ottoman period: Part of İskenderpaşa neighborhood } \\
\text { and the whole of } 1^{\text {st }} \text { Çömlekçi neighborhood }\end{array}$ \\
\hline $\begin{array}{l}\text { Between } 1800 \text { and } \\
1900\end{array}$ & $\begin{array}{l}\text { Settlements in the Ottoman period: The whole of Gazipaşa } \\
\text { neighborhood, parts of Cumhuriyet and } 1^{\text {st }} \text { Çömlekçi neighborhoods }\end{array}$ \\
\hline $\begin{array}{l}\text { Between } 1900 \text { and } \\
1923\end{array}$ & $\begin{array}{l}\text { Settlements in the Ottoman period: Parts of Boztepe, Ayasofya, Kavak } \\
\text { Meydan1, Yenicuma and erdoğdu neighborhoods }\end{array}$ \\
\hline After 1923 & $\begin{array}{l}\text { Settlements in the Republic of Turkey: The whole of Yenimahalle, } \\
\text { Kurtuluş, Yalı, Bahçecik, } 2^{\text {nd }} \text { Çömlekçi and Zafer Neighborhoods, and parts } \\
\text { of Ayasofya, Kavak Meydanı, Erdoğdu, Gülbaharhatun and Boztepe } \\
\text { neighborhoods }\end{array}$ \\
\hline
\end{tabular}

\begin{tabular}{|c|c|}
\hline \multicolumn{2}{|c|}{ City Planning Works } \\
\hline 1933 & $\begin{array}{l}\text { In the republican period, the Ottoman "Development Plan Law" (Ebniye } \\
\text { Law) of } 1882 \text { was replaced by the Law no } 2290 \text { "Law of Municipalities and } \\
\text { Roads" }\end{array}$ \\
\hline 1937 & $\begin{array}{l}\text { The first planning work: It was prepared by a French city planner, } \\
\text { J.H.Lambert, and was put into effect in } 1938 \text {. }\end{array}$ \\
\hline 1939 & $\begin{array}{l}\text { The 3rd General Inspector Tahsin Report was prepared in accordance with } \\
\text { the guidelines in the report prepared by Lambert in } 1937 .\end{array}$ \\
\hline After 1950 & Fast urbanization \\
\hline 1957 & Development Plan Law no 6785 \\
\hline 1964 & Construction of the first coastal road \\
\hline 1965 & Fast urbanization \\
\hline $1967-1968$ & $\begin{array}{l}\text { The second planning work: With the "Analytical Surveys of Trabzon" } \\
\text { prepared by the provincial Bank of Turkey, the development plan was put } \\
\text { into contest. The contest was won by H. Kaplan, E. Aysu, I. Bayhan, R. } \\
\text { Şehvardar. The winning project was put into practice in } 1970 \text {. }\end{array}$ \\
\hline 1984 & Illegal constructions were legalized with the law no 2981. \\
\hline 1985 & $\begin{array}{l}\text { Authority for the approval of constructions were given to local authorities } \\
\text { with the Law No } 3194\end{array}$ \\
\hline $1988-89$ & The revised development plan was prepared \\
\hline 2002 & Construction of the Tanjant Road \\
\hline
\end{tabular}




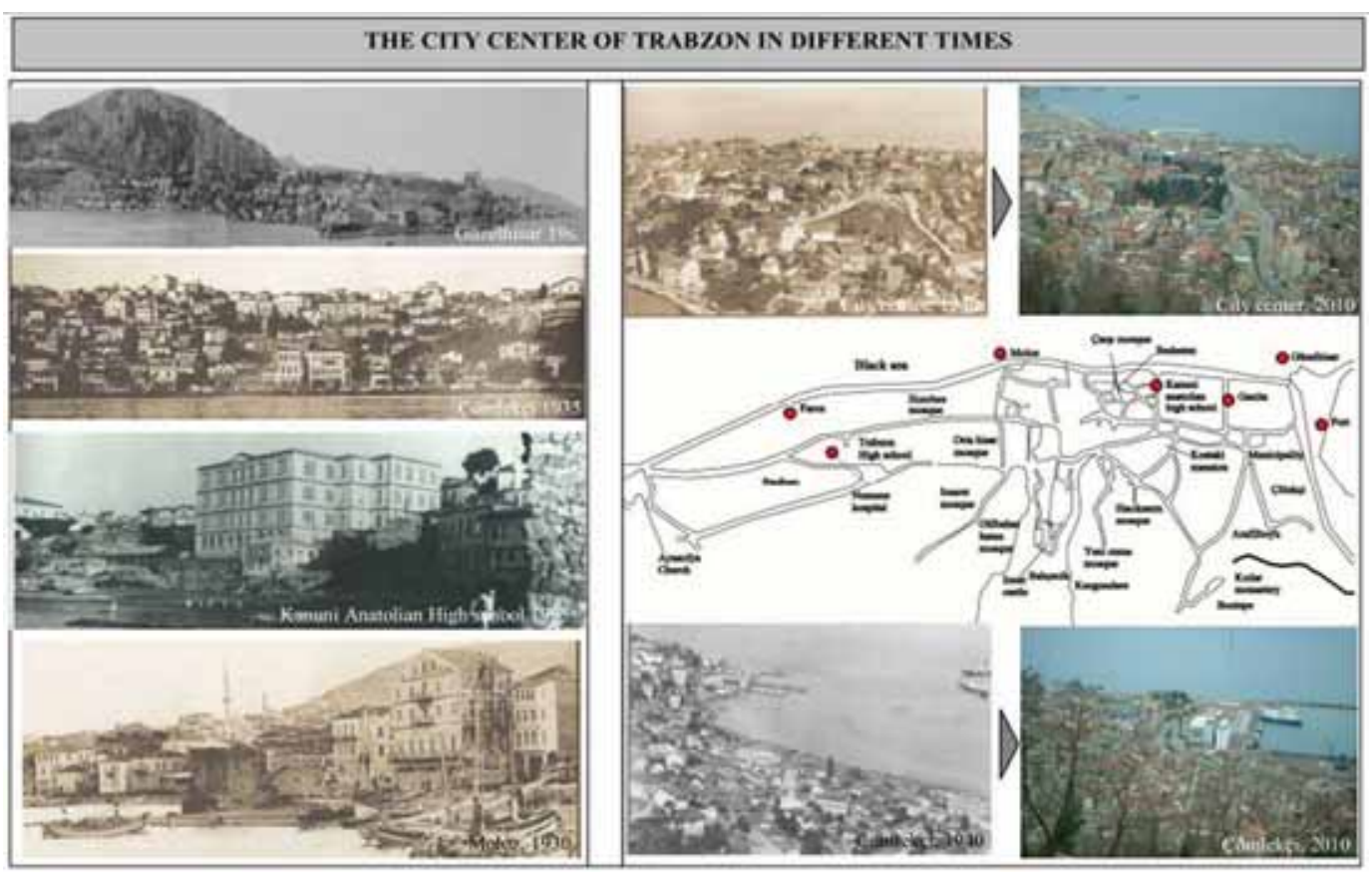

Figure 1. The City center of Trabzon in different times

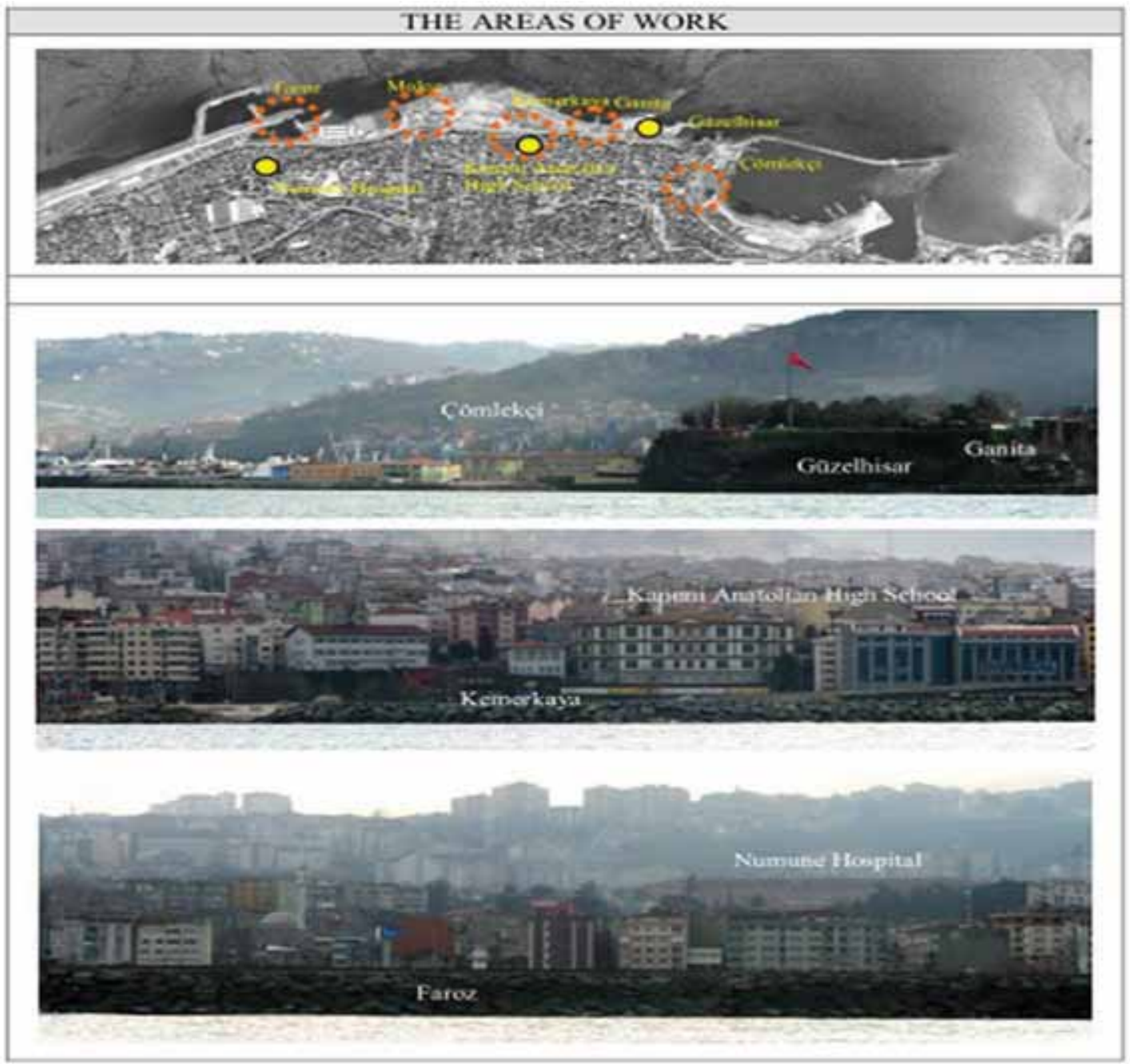

Figure 2. Areas in Trabzon that were studied 


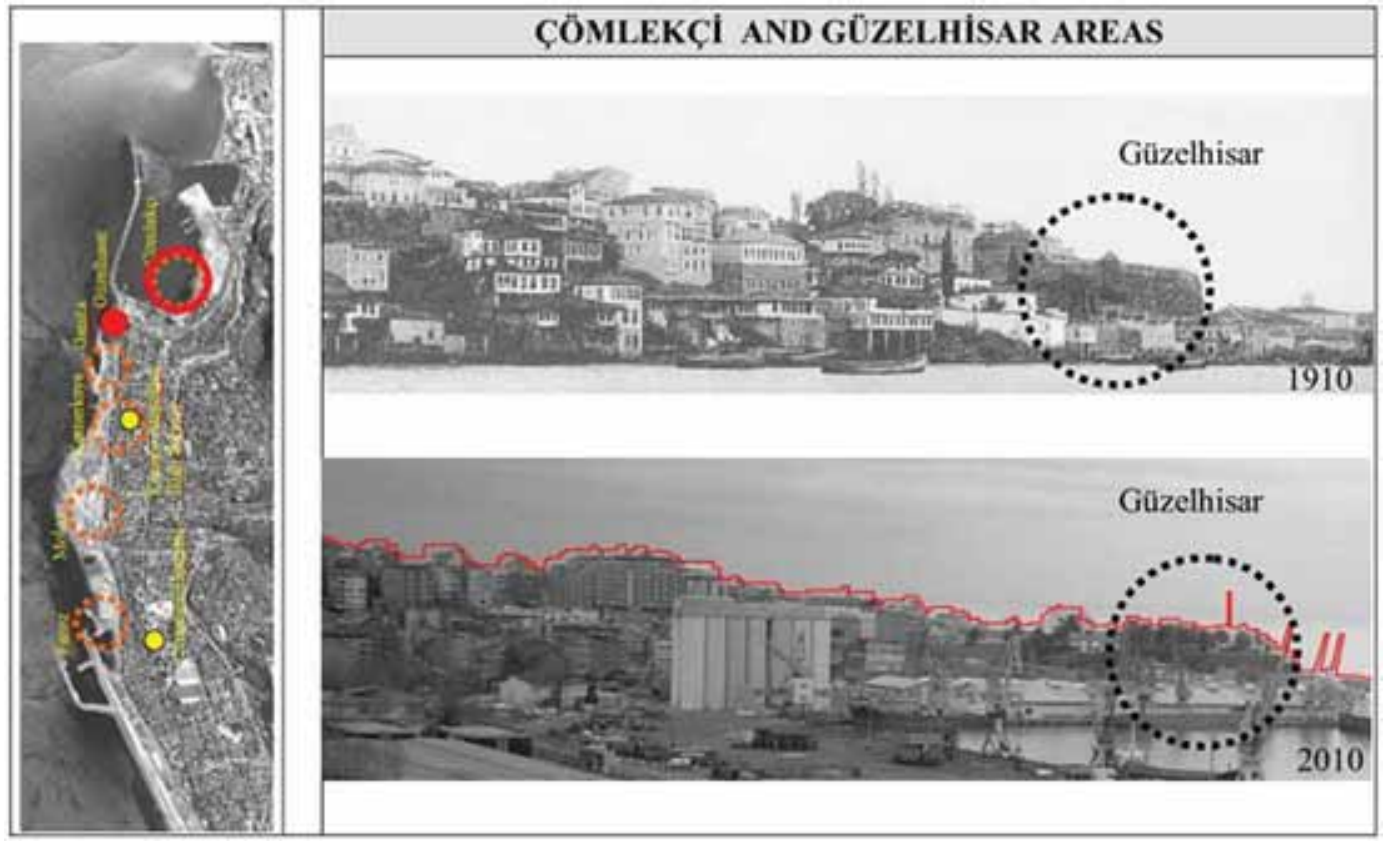

Figure 3. Çömlekçi and Güzelhisar Areas

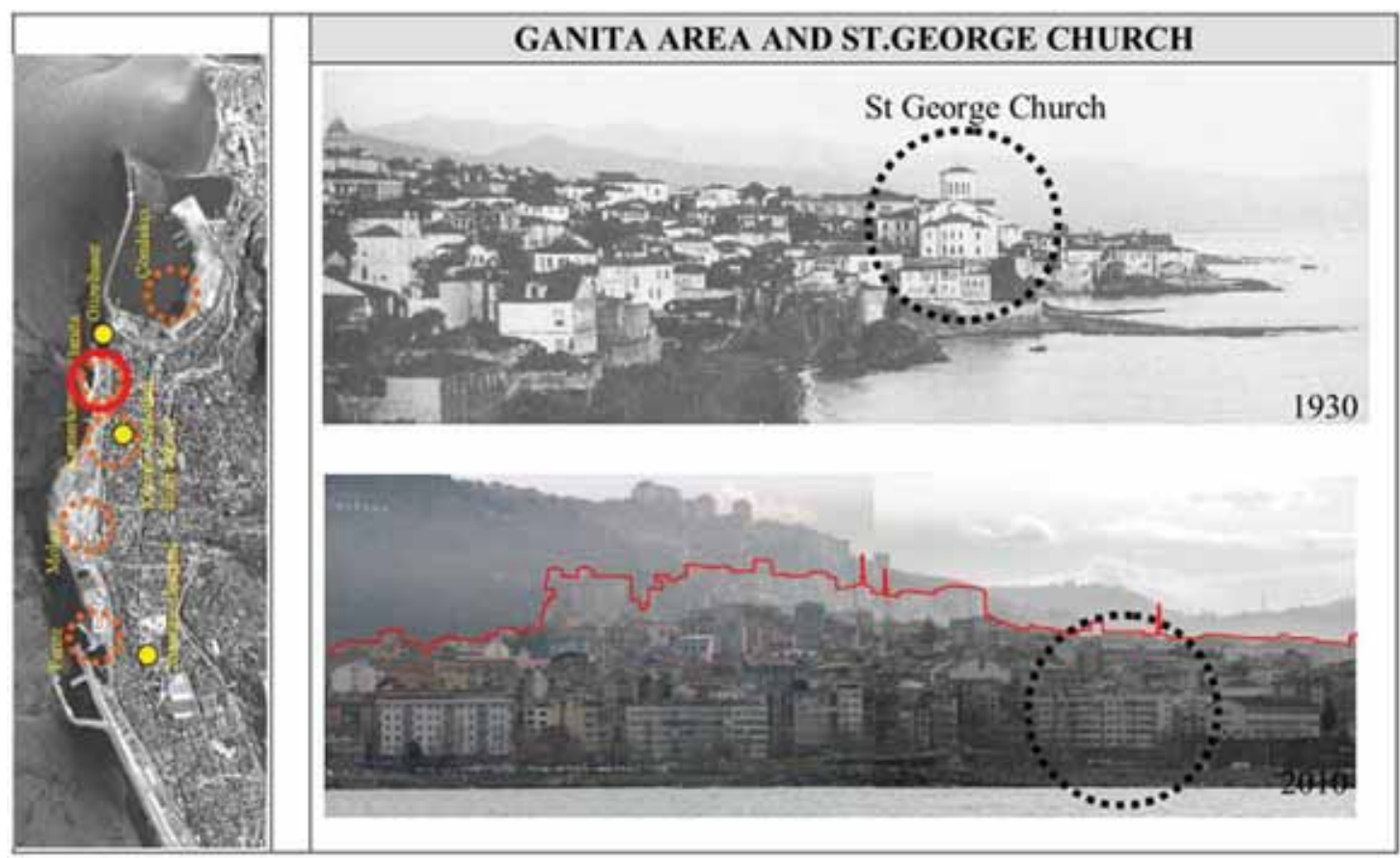

Figure 4. Ganita area and St.George Church 


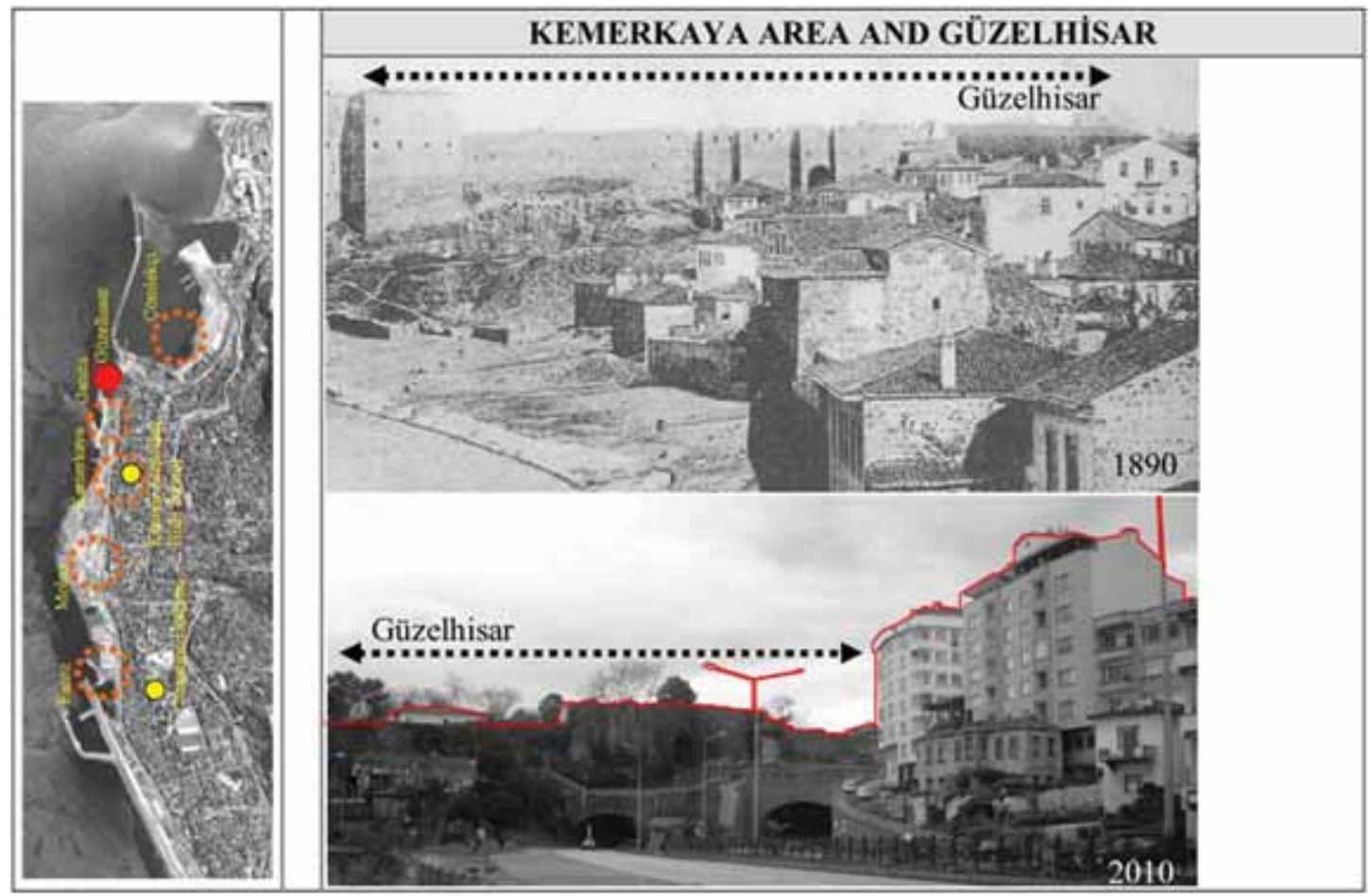

Figure 5. Kemerkaya Area and Güzelhisar

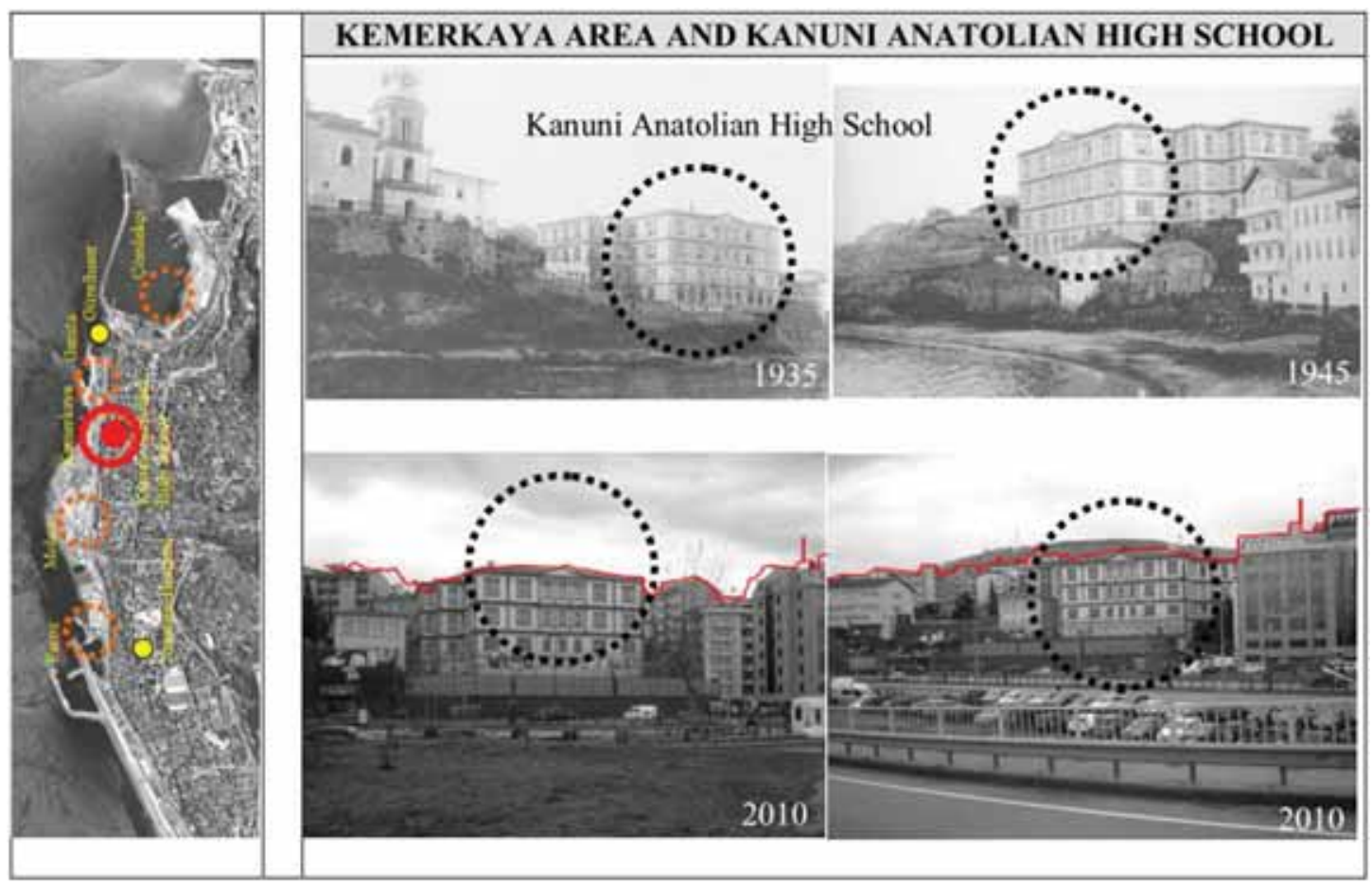

Figure 6. Kemerkaya Area and Kanuni Anatolian High School 


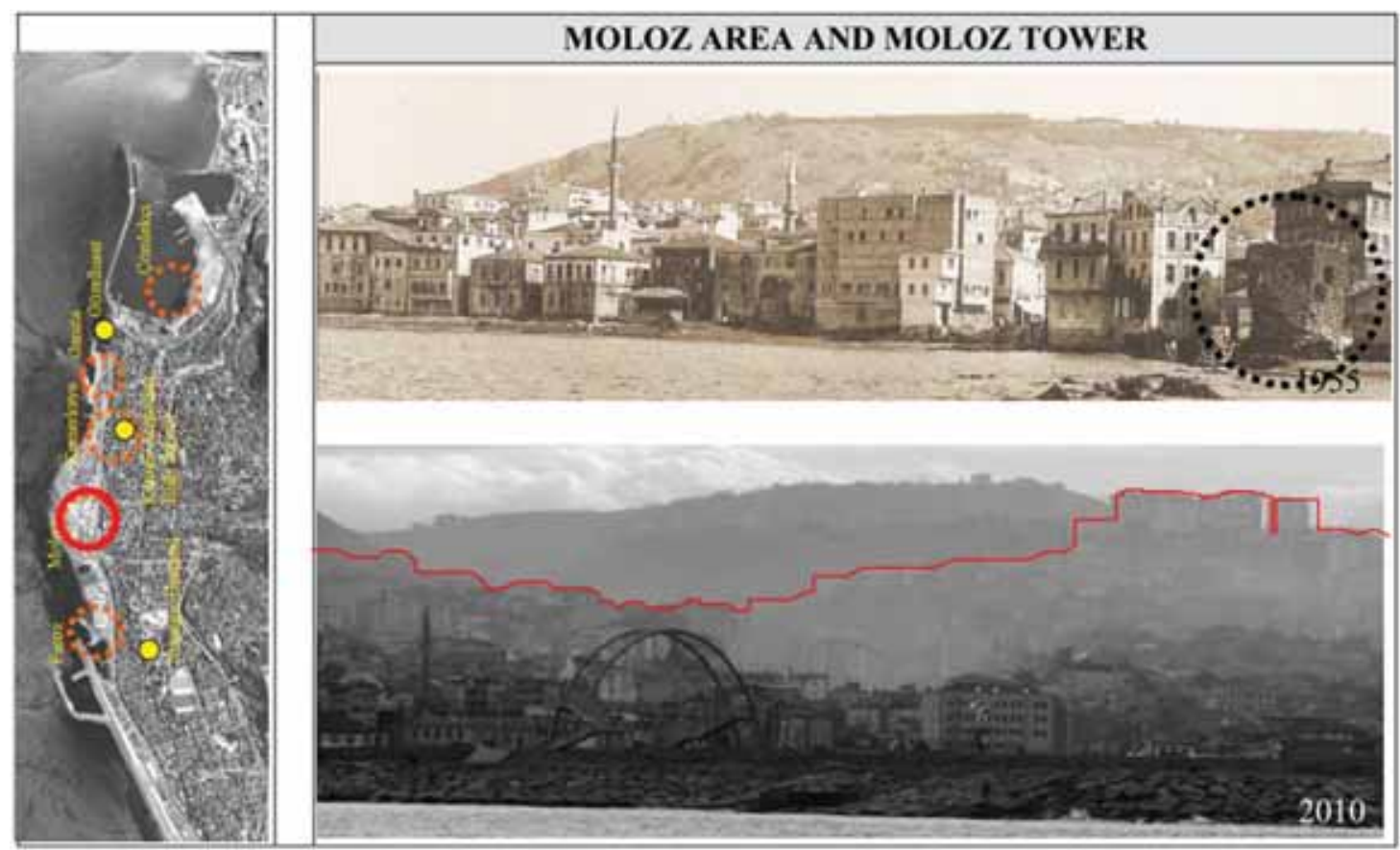

Figure 7. Moloz Area and Moloz Tower
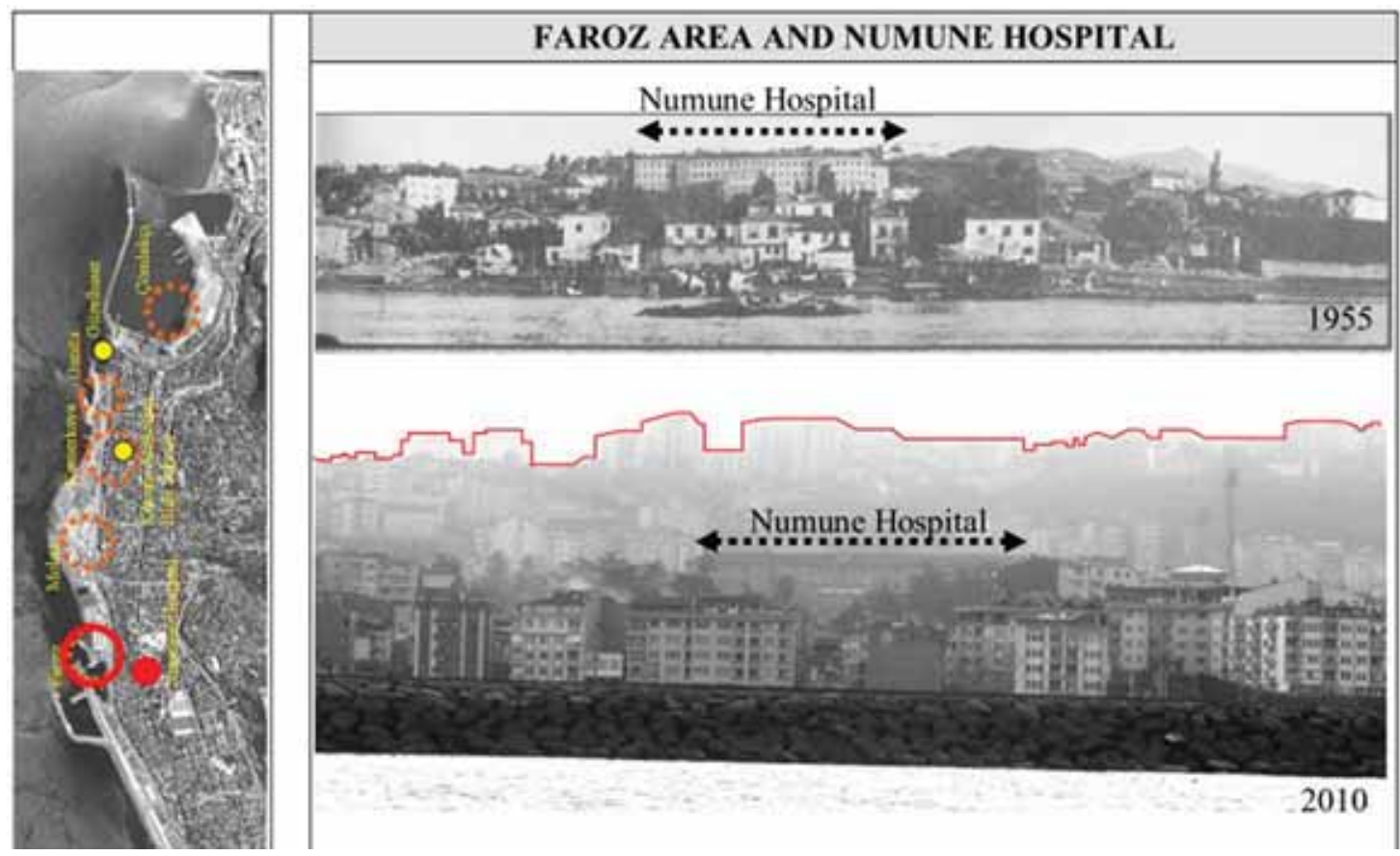

Figure 8. Faroz Area and Numune Hospital 